\section{Functional Analysis of the Iron(II) Etiocorrphycene Incorporated in the Myoglobin Heme Pocket}

\author{
Saburo NeYA, ${ }^{*, a}$ Mihoko NaKAmURA, ${ }^{a}$ \\ Kiyohiro IMAI, ${ }^{b}$ and Noriaki FunASAKI ${ }^{a}$
}

Department of Physical Chemistry, Kyoto Pharmaceutical University, ${ }^{a}$ Yamashina, Kyoto 607-8414, Japan and Department of Physiology and Biosignaling, Graduate School of Medicine, Osaka University, ${ }^{b}$ Yamadaoka, Suita, Osaka 565-0871, Japan.

Received December 15, 2000; accepted January 30, 2001

The iron(II) complex of 2,7,12,17-tetraethyl-3,6,11,18-tetramethylcorrphycene, an isomeric heme, was complexed with apomyoglobin to examine the ligand binding ability of the novel macrocycle under physiological conditions. The reconstituted holoprotein was found to be functionally active at $\mathbf{p H ~} 7.4$ and $20{ }^{\circ} \mathrm{C}$ and to bind oxygen and carbon monoxide reversibly with a half-saturation pressure at 6.7 and $3.5 \mathrm{mmHg}$, respectively. Equilibrium affinities for these ligands are one to two orders of magnitude lower than those reported for native myoglobin. The functional anomaly was ascribed to the geometric and electronic strain on the iron(II) atom in the trapezoidal coordination core of corrphycene.

Key words iron(II) corrphycene; reconstituted myoglobin; oxygen binding; deformed coordination core

Aspiration is the most basic biological process in all aerobic organisms. Oxygen $\left(\mathrm{O}_{2}\right)$ from the lung is stored in muscle by myoglobin $(\mathrm{Mb})$. The ability of $\mathrm{Mb}$ depends on the intimate linkages of the prosthetic group with the surrounding globin. The heme in $\mathrm{Mb}$ is the iron(II) complex of protoporphyrin IX with several types of peripheral substituents. Chemical modification of heme substituents has been carried out to analyze the heme-protein interactions in $\mathrm{Mb} .{ }^{1)}$ However, the fundamental structure of the porphyrin skeleton has never been altered.

Corrphycene is a novel structural isomer of porphyrin synthesized by Sessler et al. in 1994. ${ }^{2}$ The macrocycle is formally derived from porphyrin by removing one meso-carbon to the diagonal bridge. The structural change deforms the square metallo cavity of porphyrin into a trapezoid, although the resultant corrphycene remains flat and aromatic like the parent porphyrin. The obvious similarities between corrphycene and porphyrin inevitably suggest the potential utilization of iron(II) corrphycene as an oxygen carrier. Although such a skeletal arrangement as found in corrphycene is unlikely to occur in nature, it is of primary interest to examine the binding ability of the iron(II) complex for $\mathrm{O}_{2}$ under physiological conditions. Is it possible for the irregular porphyrinoid to be placed in $\mathrm{Mb}$ as the prosthetic group? What type of perturbation is expected for the reconstituted $\mathrm{Mb}$ ? We report here the first functional analyses of the artificial $\mathrm{Mb}$ reconstituted with 2,7,12,17-tetraethyl-3,6,11,18tetramethylcorrphycenatoiron(II), the iron(II) complex of etiocorrphycene (Fig. 1).

\section{Experimental}

2,7,12,17-Tetraethyl-3,6,11,18-tetramethylcorrphycene ${ }^{3)}$ and the iron(III) complex ${ }^{4}$ were prepared according to the method reported in the literature. Sperm whale Mb (Sigma, type II) was obtained commercially. The crude
$\mathrm{Mb}$ reconstituted with etiocorrphycenatoiron(III) was purified by column chromatography with a linear gradient of Tris buffer, $20-120 \mathrm{~mm}$, on a carboxymethylated-cellulose (Whatman, CM52) column after the preparation of the Mb-bearing etiohemin. ${ }^{5)}$ The $\mathrm{O}_{2}$ equilibrium curve of the $\mathrm{Mb}$ was recorded on the automatic recording apparatus of Imai ${ }^{6}$ in the presence of an enzymic reduction system. ${ }^{7)}$ The carbon monoxide (CO) affinity was optically determined by titrating $\mathrm{CO}$-saturated $0.1 \mathrm{~m}$ Tris buffer to the oxy $\mathrm{Mb}$ solution at $\mathrm{pH} 7.4$ and $20^{\circ} \mathrm{C}$. Visible absorption spectra were recorded on a Shimadzu MPS-2000 spectrophotometer with a cell compartment equipped with a circulating water bath.

\section{Results}

Etiocorrphycenatoiron(III) is an all-alkyl compound essentially insoluble in water. Insolubility in water, however, did not prevent the $\mathrm{Mb}$ reconstitution because the procedure used for etiohemin ${ }^{5)}$ afforded a $50-60 \%$ yield. Preliminary optical titration of the corrphycenatoiron(III) to apoMb, as monitored at $410 \mathrm{~nm}$, further revealed a clear inflection point at a $1: 1$ binding stoichiometry. Purified ferric $\mathrm{Mb}$ showed light absorption maxima at $280\left(34 \mathrm{~mm}^{-1} \mathrm{~cm}^{-1}\right), 406$ (101), 521 (6.9), 550 (shoulder), and 654 (1.9) $\mathrm{nm}$ in $0.1 \mathrm{M}$ Tris at $\mathrm{pH}$ 7.0 and $20^{\circ} \mathrm{C}$ (result not shown). The ferrous $\mathrm{Mb}$ reduced with the enzymatic system ${ }^{7)}$ was stable to afford reversible $\mathrm{O}_{2}$ binding. Figure 2 shows the visible absorption spectra of the oxy and deoxy derivatives. Figure 3 illustrates the Hill plots of $\mathrm{O}_{2}$ binding characterized with a Hill coefficient $n=1.00$ and a half-saturating pressure $P_{50}=6.7 \mathrm{mmHg}$ or $K_{\mathrm{a}}=8.20 \times 10^{4} \mathrm{M}^{-1}$. The $\mathrm{Mb}$ is also capable of binding $\mathrm{CO}$ (Fig. 2). The $\mathrm{CO}$ affinity was estimated by the $\mathrm{CO}$ replacement of oxy Mb. Titration of CO-saturated buffer to the oxy $\mathrm{Mb}$ resulted in the formation of a sharp 406-nm Soret peak

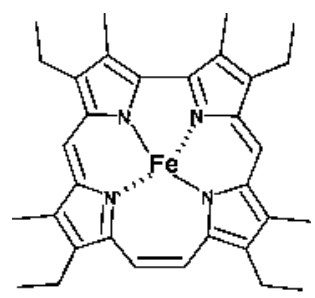

Fig. 1. Iron(II) Complex of Etiocorrphycene Employed as the Prosthetic Group of $\mathrm{Mb}$

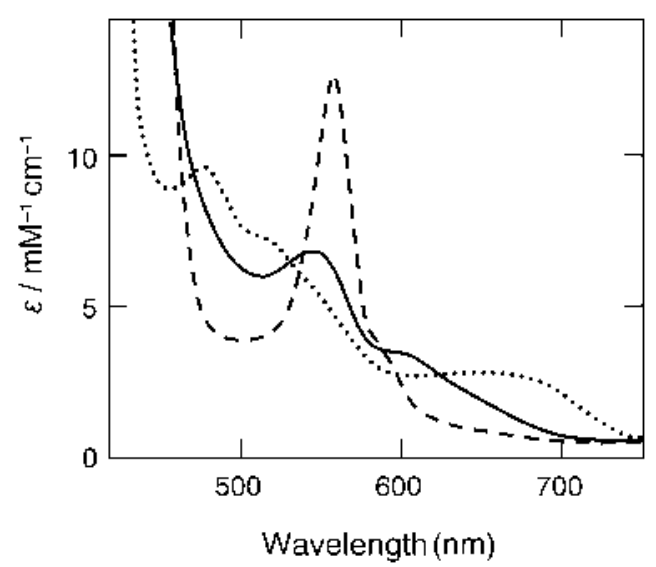

Fig. 2. Visible Absorption Spectra of the Oxy (-), Deoxy (---), and Carbonmonoxy $(\cdots)$ Forms of Mb Reconstituted with Etiocorrphycene in $0.1 \mathrm{M}$ Tris at $\mathrm{pH} 7.4$ and $20^{\circ} \mathrm{C}$

Soret bands of the oxy, deoxy, and carbonmonoxy derivatives are at $410\left(80 \mathrm{~mm}^{-1}\right.$ $\left.\mathrm{cm}^{-1}\right), 434(115)$, and $406(182) \mathrm{nm}$, respectively. 


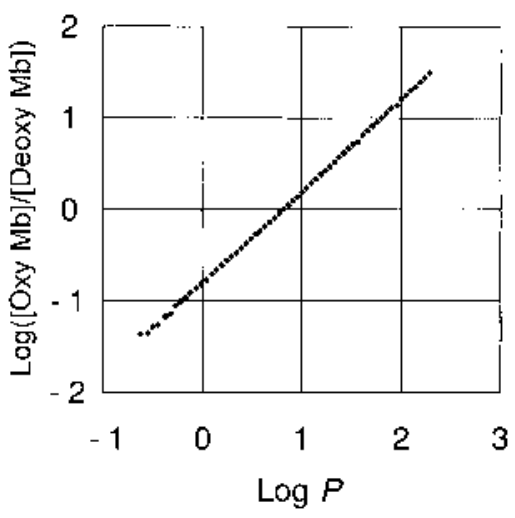

Fig. 3. Hill Plots of the Equilibrium $\mathrm{O}_{2}$ Binding to the Deoxy Mb Containing Etiocorrphycene

Monitored at $558 \mathrm{~nm}$ in $0.1 \mathrm{M}$ phosphate at $\mathrm{pH} 7.4$ and $20^{\circ} \mathrm{C} . P$, partial $\mathrm{O}_{2}$ pressure in $\mathrm{mmHg}$.

with isosbestic points at 394 and $414 \mathrm{~nm}$. The partition coefficient $[\mathrm{MbCO}]\left[\mathrm{O}_{2}\right] /\left[\mathrm{MbO}_{2}\right][\mathrm{CO}]=2.86$ afforded $P_{50}=3.5$ $\mathrm{mmHg}$ or $K_{\mathrm{a}}=2.1 \times 10^{5} \mathrm{M}^{-1}$ for the CO ligation in $0.1 \mathrm{M}$ Tris buffer at $\mathrm{pH} 7.4$ and $20^{\circ} \mathrm{C}$. Briefly, the $\mathrm{O}_{2}$ and $\mathrm{CO}$ affinities of etiocorrphycene $\mathrm{Mb}$ are reduced to $1 / 13$ and $1 / 128$, respectively, as compared with $K_{\mathrm{a}}=1.10 \times 10^{6} \mathrm{M}^{-1}\left(\mathrm{O}_{2}\right)$ and $2.7 \times 10^{7} \mathrm{M}^{-1}(\mathrm{CO})$ of native $\left.\mathrm{Mb}^{8}\right)^{{ }^{\mathrm{a}}}$

\section{Discussion}

The 1:1 complex formation between the iron(III) corrphycene and apoprotein suggests their successful coupling to produce reconstituted $\mathrm{Mb}$. The apparently normal coordination of $\mathrm{O}_{2}$ and $\mathrm{CO}$ provides support to the structural integrity of the $\mathrm{Mb}$. It is now evident that the iron(II) etiocorrphycene serves as the prosthetic group of $\mathrm{Mb}$. To our knowledge, this is the first demonstration of etiocorrphycenatoiron(II) as a carrier of $\mathrm{O}_{2}$ and $\mathrm{CO}$. The quantitative comparison of the ligand binding profiles with native $\mathrm{Mb}$ reveals functional anomalies. The $\mathrm{O}_{2}$ affinity of corrphycene $\mathrm{Mb}$ is only $1 / 13$ that of native $\mathrm{Mb}^{8)}$ under comparable conditions. It could be argued that the much lower $\mathrm{O}_{2}$ affinity may indicate the absence of propionic acid groups in the corrphycene. The possibility is ruled out because heme propionate groups only slightly affect the $\mathrm{O}_{2}$ affinity of $\mathrm{Mb}^{5,8)}$ It could also be argued that the insertion of the isomeric heme may induce conformational transition of the heme pocket to disturb ligand binding. This is also unlikely because crystallographic analyses of the $\mathrm{Mb}^{9,10)}$ reconstituted with synthetic hemins revealed that the globin conformation is fairly insensitive to the molecular shape of the prosthetic group. In view of the results, ${ }^{9,10)}$ the corrphycene-Mb is likely to retain the native conformation, although some minor conformational transition of the distal histidine cannot be ruled out.
The functional anomaly most likely arises from the peculiar molecular shape of corrphycene. The metallo cavity is trapezoidal in corrphycene, ${ }^{2)}$ in remarkable contrast with the square cavity in porphyrin. The deformed equatorial ligand field could cause unfavorable overlap of the electron lobes of the four pyrrole-nitrogens with the iron $d_{x^{2}-y^{2}}$ orbital. The iron atom under these circumstances is readily displaced from the corrphycene plane. The possible large iron displacement toward the proximal histidine, similar to the T-state of hemoglobin, ${ }^{11)}$ could significantly reduce the $\mathrm{O}_{2}$ and $\mathrm{CO}$ affinities.

Since the iron(II) $-\mathrm{O}_{2}$ bond in heme has both $\sigma$ and $\pi$ characteristics in almost equal proportions, ${ }^{12)}$ it is not always easy to evaluate the changes in the two types of bonding interactions from the $\mathrm{O}_{2}$ equilibrium curve alone. Consideration of the $\mathrm{CO}$ binding result allows us to elucidate the bonding effects. It is noteworthy that the reduction $(1 / 128)$ in $\mathrm{CO}$ affinity is much larger than the decrease $(1 / 13)$ in $\mathrm{O}_{2}$ affinity. Since the $\pi$-type interaction dominates in iron(II)-CO interactions, ${ }^{13)}$ the significantly lower $\mathrm{CO}$ affinity reasonably suggests decreased iron(II) $\mathrm{d} \pi-\mathrm{CO} \mathrm{p} \pi$ interactions. In other words, the energy level of the iron $d_{x z}$ and $d_{y z}$ orbitals in corrphycene is enhanced to destabilize iron(II)-CO bonding. It is thus likely that the deformed metallo core in corrphycene is the direct cause of the remarkable reduction in the affinity for $\mathrm{O}_{2}$ and $\mathrm{CO}$. We therefore conclude that etiocorrphycene is a potential modulator of the ligand binding ability of $\mathrm{Mb}$.

Acknowledgments We thank Dr. Seiji Ishikawa, Kyoto Pharmaceutical University, for editorial help. This work was supported by grants-in-aid (\#10672031 and Frontier Research Program) from the Ministry of Education, Science, Sports, and Culture, Japan.

\section{References}

1) Sano S., "The Porphyrin," Vol. 7, ed. by Dolphin, D., Academic Press, New York, 1979, pp. 377-402.

2) Sessler J. L., Brucker E. A., Weghorn S. J., Kisters M., Shäfer M., Lex J., Vogel E., Angew. Chem. Int. Ed. Engl., 33, 2308-2312 (1994).

3) Neya S., Nishinaga K., Ohyama K., Funasaki N., Tetrahedron Lett., 39, 5217-5220 (1998).

4) Adler A. D., Longo F. R., Kampas F., Kim J., J. Inorg. Nucl. Chem., 32, 2443-2445 (1970).

5) Neya S., Funasaki N., Imai K., Biochim. Biophys. Acta, 996, 226-232 (1989).

6) Imai K., Methods Enzymol., 76, 438-449 (1981).

7) Hayashi A., Suzuki T., Shin M., Biochim. Biophys. Acta, 310, 309316 (1973).

8) Springer A. P., Sliger G. S., Olson J. S., Phillips G. N., Jr., Chem. Rev., 94, 699-714 (1994).

9) Neya S., Funasaki N., Sato T., Igarashi N., Tanaka N., J. Biol. Chem., 268, 8935-8942 (1993).

10) Neya S., Funasaki N., Ikezaki A., Sato T., Imai K., Tanaka N., Biochemistry, 37, 5487-5493 (1998).

11) Collman J. P., Fu L., Acc. Chem. Rev., 32, 455-463 (1999).

12) Momenteau M., Reed C. A., Chem. Rev., 94, 659-698 (1994).

13) Shriver D. F., Atkins P. W., Langford C. H., "Inorganic Chemistry," 2nd ed., Oxford University Press, Oxford, 1994, pp. 666-668. 